\title{
PARTS OF SPEECH ANALYSIS APPEARED ON HEADLINES NEWSPAPER
}

\author{
${ }^{1}$ Rakhmat Wahyudin Sagala, ${ }^{2}$ Tri Indah Rezeki, \\ ${ }^{1}$ Universitas Muhammadiyah Sumatera Utara \\ rakhmatwahyudin@umsu.ac.id \\ ${ }^{2}$ STKIP Budidaya Binjai \\ trindah.rizky@gmail.com
}

\begin{abstract}
Newspaper is one kind of mass media that plays a very important role in organizing public opinion. The aim of this study is to analyze the use of parts of speech appeared on headlines of The Jakarta Post Newspaper. Descriptive qualitative research was applied in this study and collected the data from the words on headlines The Jakarta Post Newspaper on November $23^{\text {rd }}, 2019$ which contain parts of speech. Based on the data result, The Jakarta Post has 11 news headlines. Total words count is 71. Noun, Verbs and Prepositions were frequently used as compared to other parts of speech. Nouns consist of 43 words, Verbs consists of 12 words, Prepositions consist of 10 words, adverbs consist of 3 words, adjectives consist of 2 words, conjunction consists of 1 word and there were no pronoun and interjection found in the headlines of The Jakarta Post newspaper.
\end{abstract}

Keywords: Parts of speech; Headlines; Newspaper

\section{INTRODUCTION}

Because of language is one of important thing in human society's life to communicate each other (Sagala, 2019), we should consider pack of words that partition grammatical masters. These gatherings are called Parts of Speech. In a language, Parts of Speech are an established terminology used for the major classes of words that are grammatically distinguished. Every language has their own classification in which they define Parts of Speech. It varies from one language to another. These differences between languages lead to the division basis on both kind and number.

In traditional grammar, a part of speech is a category of words (or, more generally, of lexical items) that have similar grammatical properties. Words that are assigned to the same part of speech generally display similar syntactic behavior. Croft (2000) explains that Parts of Speech play similar roles within the grammatical structure of sentences and sometimes similar morphology in that they undergo inflection for similar properties. Commonly, there are eight parts of speech namely noun, verb, adjective, adverb, pronoun, preposition, conjunction, interjection.

A noun is a word used to name a person, place, or thing. According to their kinds, English nouns can be categorized into 2 kinds, i.e. (1) proper, and (2) common nouns which are divided into (a) abstract, (b) individual, and (c) collective nouns. A noun which indicates one object only, it is a singular noun. When a noun indicates more than one, it is plural noun. 


\section{Jurnal Serunai Ilmu Pendidikan \\ Vol.5, No.2, Desember 2019 \\ e-ISSN 2621 - 2676}

Verb is the main word in the predicate of a sentence that expresses action or being.

An adjective modifies a noun or a pronoun and also tells the quality of a noun or a pronoun such as beautiful, handsome, etc.

An adverb is the one which modifies verbs, adjective or another adverb such as clearly, slowly, etc.

Pronouns replaces noun at various positions and for various reasons. Personal pronouns are (I, you, he, she, it, we, they, me, him, her, us, and them) which shows contrasts of person, gender, number, and case.

A preposition is a word that shows the relationship between a noun and some other word in the sentence such as up, of, since, etc.

A conjunction is another important element of parts of speech. Conjunctions are connectors of the clauses or phrases to render a sense to a sentence or serve the purpose of coordinating words in the clauses such as and, but, or, etc.

Interjection is a word or words that show feeling. If it stands alone, it is followed by an exclamation point. If it begins a sentence, it is set off by a comma.

A paper headline is repeatedly the only thing that readers look forward to at the first place in a newspaper, or at least, it is the most prominent thing that majority keeps focus on. Between all the media platforms, newspaper has the most prolonged history, arising from the ceremonial newspaper in China (Liu Lu, 2002). The time when it was published, there had been many studies related news. As newspapers are medium of judgement, the announcement when the reporter puts into the current dated paper; exercises an impact on public judgements in a larger version. The reason behind is that the headlines provide the most important and priceless piece of fact to the reader in lesser words, it plays a discreet important role in news report. (Zhijun,1998).

A headline must possess a legitimate sentence construction comprising of a subject and a respective verb as per the changes in situation; generally features do not think of helpers, conjunctions, articles, pronouns or conjunctions. It characterizes the lone lexical instead of grammatical function. The most extensive purpose behind that is the space particularly given for every feature and the settling issue of the best words may approach.

Attractive front-page headlines force the buyers to purchase that newspaper. Moreover, enchanting the buyers to read the news stories by putting forward the appealing stories as every headline narrates the main news and the basic details, which permit the readers to seek positivity from important ideas even when they go through the page.

Every news story has some components and among all headlines is the most essential one.

The purpose of the headline is to provoke reader's attention. It also makes them read the complete article. Another purpose of a headline is to sell the news by grabbing the attention of its reader. Headlines give a direction to the reader as it provides them a framework for the reading process. According to Fries, reader starts to read the text of the article with the headline. After reading the text he connects the text with the headline and will do every possible thing to connect it to the headline.

According to LaRocque (2003), the maker of the headlines knows well what they want but there are other difficulties which need to be resolved before making a headline such as space or their own abilities which include vocabulary, creativity, knowledge of the language etc.).

Headlines are different than the rest of the newspaper. Its language makes it 
different among all. Mardh (1980) illustrates that a headline should be short enough that it is readable and long enough that it specifies all the important fact and figures. Moreover, the length of a heading should not be more than seven words.

The Jakarta Post is a daily English language newspaper in Indonesia. The paper is owned by PT Niskala Media Tenggara and based at the nation's capital, Jakarta. The Jakarta Post also features an online edition and a weekend magazine supplement called $\mathrm{J}+$. The newspaper is targeted at foreigners and educated Indonesians, although the middle-class Indonesian readership has increased.

Because of the most important parts of speech give the significant content to a message in newspaper, are generally called content words, the researchers are interested to conduct a study about parts of speech analysis appeared on headlines of The Jakarta Post newspaper.

\section{METHOD}

Descriptive qualitative research was applied in this study. Descriptive qualitative research involves collecting data in order to test hypothesis or to answer the question concerning the current status of the subject of the study (Gay and Airisian, 2000). Descriptive qualitative research is a design to obtain information concern the current status phenomena. It is directed toward determining the nature of a situation as it exist at the time of the study (Ary, 2006). In qualitative research, the researcher is an actor to collect the data (Moleong, 2011).

The data of this study was the headlines of The Jakarta Post newspaper on November $23^{\text {rd }}$ 2019. It has 11 news headlines and the total word count is 71 words.

\section{RESULT AND DISCUSSION}

\section{a. Data Analysis of Parts of Speech}

Croft (2000) divided eight parts of speech namely noun, verb, adjective, adverb, pronoun, preposition, conjunction, interjection. The data analysis of parts of speech on headlines of The Jakarta Post can be seen in table 3.1.

Table 1. Data Analysis of Parts of Speech

\begin{tabular}{|c|c|c|c|}
\hline No & $\begin{array}{l}\text { Parts of } \\
\text { Speech }\end{array}$ & Words & Amount \\
\hline 1. & Noun & $\begin{array}{l}\text { Climate, change, } \\
\text { drought, PSSI, } \\
\text { assault, KL, } \\
\text { stadium, } \\
\text { commentary, } \\
\text { Bahtiar Efendy, } \\
\text { Muslim, public, } \\
\text { intellectual, } \\
\text { champion, } \\
\text { democracy, lack, } \\
\text { sex, education, } \\
\text { risk, HIV, Ahok, } \\
\text { Pertamina, } \\
\text { President, } \\
\text { commissioner, } \\
\text { Bandung, } \\
\text { chickens, gadgets, } \\
\text { migrant, worker, } \\
\text { protection, } \\
\text { activists, } \\
\text { government, } \\
\text { Frozen 2, parents, } \\
\text { kids, travel, } \\
\text { moments, demand, } \\
\text { photography, } \\
\text { LRT, Jakarta, } \\
\text { commercial, } \\
\text { operations, } \\
\text { December }\end{array}$ & 43 \\
\hline 2. & Verb & $\begin{array}{l}\text { Brings, probes, } \\
\text { raises, appointed, } \\
\text { turns, get off, } \\
\text { should, begin, tell, } \\
\text { enchants, } \\
\text { immortalize, start }\end{array}$ & 12 \\
\hline 3. & Adjective & Worst, precious & 2 \\
\hline 4. & Adverb & $\begin{array}{l}\text { 2015, outside, at } \\
\text { home }\end{array}$ & 3 \\
\hline 5. & Pronoun & - & \\
\hline 6. & Preposition & Since, of (3), to & 10 \\
\hline
\end{tabular}




\begin{tabular}{|c|c|c|}
\hline \multicolumn{3}{|c|}{ (3), with, on, in } \\
\hline 7. & Conjunction And & 1 \\
\hline 8. & Interjection & \\
\hline \multicolumn{2}{|r|}{ Total } & 71 \\
\hline
\end{tabular}

Based on the data analysis, it can be seen that there are five parts of speech used on the headline of The Jakarta Post newspaper on November $23^{\text {rd }} 2019$ namely nouns consist of 43 words, verbs consist of 12 words, adjectives consists of 2 words, adverbs consist of 3 words, prepositions consist of 10 words, conjunction consists of 1 word. While pronoun and interjection were not found on the headline news.

\section{CONCLUSION}

Parts of Speech as an established terminology used for the major classes of words that are grammatically distinguished can be found in the headlines of The Jakarta Post newspaper. Based on the data result, there are 5 parts of speech include 71 words are found in the headlines news.

\section{REFERENCES}

Airasian, P and L. R. Gay. 2000. Educational Research: Competencies for Analysis and Application Sixth Edition. New
Jersey: Prentice Hall Inc.

Ary, D., Jacob, L., C., Rajavieh, A., Sorensen, C. 2006. Introduction to Research in Education. Canada, Thomshon Wodswort,

Croft, W. 2000. Parts of speech as language universals and as language-particular categories. Empirical Approaches to Language Typology

LaRocque, P. 2003. Heads you win: An Easy Guide to Better Headline and Caption Writing. Marion Street Press, Inc.

Liu Lu. 2002 "Headline" theory. Beijing: China Social Sciences Press

Mardh, I., 1980. Headlinese: On the Grammar of English Front Page Headlines. Malmo: Gotab

Moleong, L.J. 2011. Metodologi Penelitian Kualitatif. Bandung: Remaja Rosdakarya.

Sagala, Rakhmat Wahyudin. "LANGUAGE ACQUISITION PADA ANAK PERIODE LINGUISTIK." (2019): 8489.

Zhijun. 1998. "Headlines the art", Beijing : Chinese Press. 